\section{DELINQUENSI PADA REMAJA DAN}

\section{PENANGGULANGANNYA}

\section{Salmaini Yeli}

Fakultas Tarbiyah dan Keguruan UIN Suska Riau, Pekanbaru

\section{Abstract}

Juvinile Delinquency and its Solutions: Human development undergoes several phases. One of the phases is adolescence which is often regarded identical with disobedience. In this phase a child who was previously honest begins to change. He goes out more often than staying at home watching TV or playing games. Such a condition often makes the parents go into anxiety and fear that their child is starting to be naughty without trying to understand his real conditions. This article aims to describe children's real condition and offers some solutions to their problems.

Keywords: Delinquency, Adolescence, Education

\section{Pendahuluan}

Manusia sebagai makhluk individual memiliki tahap-tahap perkembangan yang berbeda antara satu individu dengan individu lainnya. Tahapan-tahapan tersebut dapat dikelompokkan ke dalam beberapa bagian, yaitu tahap anak-anak, remaja dan dewasa. Tahapantahapan selalu dilalui oleh orang per orang, meskipun perpindahan dari suatu tahap ke tahap berikutnya dilalui orang per orang secara berbeda.

Tahap perkembangan anak-anak merupakan perkembangan awal yang dilalui seseorang terhitung sejak seseorang lahir ke dunia hingga ia dewasa. Tahap perkembangan remaja merupakan tahapan transisi (peralihan) dari masa kanak-kanak ke masa dewasa. Pada masa kanakkanak seseorang bergantung sepenuhnya pada orang dewasa (orangtua) yang ada di sekitarnya. Dari segi fisik dapat dilihat bahwa pada masa ini bentuk fisik seseorang telah atau hampir menyamai orang dewasa. Namun dari segi pribadi anak yang meningkat remaja
Salmaini Yeli, Deliquensi Pada Remaja dan Penanggulangannya

masih tergantung pada orang dewasa (orangtua), baik dari segi pangan, sandang maupun papan, sehingga terlihat anak yang meningkat remaja mulai memperhatikan lawan jenisnya, namun ketergantungnya pada orang dewasa terkadang dirasa menghambat, hal ini akan membuat anak merasa serba salah hingga terkadang remaja terlihat uring-uringan, mau menang sendiri, dan lebih sering dan betah berada di luar rumah.

Masa remaja sering mendapat perhatian khusus dari berbagai kalangan karena tahapan ini paling banyak menimbulkan masalah. Pada saat ini si anak yang meningkat remaja dari segi sosial cenderung membentuk kelompok dan akan loyal pada aturan-aturan yang diciptakan kelompoknya. Pada masa ini anak yang meningkat remaja merasa kelompoknya lebih mengerti akan dirinya ketimbang orangtua atau anggota keluarga yang lain. Mereka mulai merasa tidak lagi disayangi, dan mereka merasa orangtua dan saudara-saudaranya yang lebih tua suka mengatur dirinya padahal mereka merasa sudah besar bahkan sama besarnya dengan orang tua dan saudara-saudaranya yang lain. Mereka tidak mau menerima perlakuan-perlakuan yang biasanya diterima anak-anak.

Bila diperhatikan secara seksama terlihat bahwa masa remaja memang mengalami keunikan dan perkembangan yang berbeda dibanding dengan tahap perkembangan yang lain. Pada masa anakanak posisi anak jelas, bahwa mereka berbeda dari orang dewasa baik secara fisik maupun psikis dan perkembangan pemikiran serta pribadi. Mereka bergantung sepenuhnya pada orangtua dan menerima semuanya dari orangtua. Sementara pada masa remaja semuanya mulai berubah. Postur tubuh anak-anak yang mereka miliki sekarang berubah perlahan dan hampir atau sudah menyamai postur tubuh orang dewasa. Begitu pula dengan organ reproduksi pada remaja sudah berfungsi seperti halnya orang dewasa. Perubahan ini juga menimbulkan masalah bagi remaja, terutama jika mereka tidak mendapatkan pengetahuan yang cukup tentang organ reproduksi yang mereka miliki. Hal ini kadangkala menyebabkan emosi remaja agak labil dan gampang tersinggung. Di samping itu berfungsinya organ reproduksi menyebabkan remaja mulai melirik dan tertarik untuk 
A1-Fikra: Jurnal Ilmiah Keislaman, Vol. 7, No. 1, Januari-Juni 2008

memperhatikan lawan jenisnya. Mereka sadar bahwa ada jenis kelamin lain selain jenis kelamin yang mereka miliki, dan mereka mulai merasa tertarik dengan jenis kelamin yang berbeda tersebut.

Munculnya kelompok-kelompok di tengah remaja yang sering dikenal dengan gang-gang menimbulkan fenomena dan masalah baru di tengah masyarakat, karena kadangkala kelompok ini bertingkah laku negatif seperti duduk-duduk di pinggir jalan dan meminta uang pada orang-orang yang melewati jalan tersebut, mengancam orang-orang yang tidak disukai atau berkelahi antar kelompok (gang) yang ada, yang kadang kala menggunakan senjata tajam. Fenomena seperti sering dijumpai di masyarakat, dan karena tahapan perkembangan remaja ini selalu ada maka sering hal itu ditemukan berulang-ulang meskipun tahapan perkembangan remaja tersebut tidak identik dengan kenakalan remaja.

Kenyataan di atas membuat penulis merasa tertarik untuk menuangkan sedikit pemikiran di sekitar remaja, yaitu masalah delinquency atau yang lebih dikenal dengan kenakalan remaja, dengan harapan sumbangan pemikiran penulis ini dapat dijadikan salah satu solusi untuk mengatasi masalah delinquency (kenakalan remaja) di masyarakat.

\section{Mengenal Tahap Perkembangan Remaja}

Tahap perkembangan remaja terjadi pada waktu usia anak sekitar umur 11 sampai 21 tahun. Tahap perkembangan remaja ini dapat dikelompokkan pada dua tahapan yaitu perkembangan remaja awal dimulai usia 11 sampai 16 tahun dan perkembangan remaja akhir dari usia 17-21 tahun. Di mana pada tahapan pertama ciri-ciri remaja lebih banyak mendekati anak-anak sementara pada tahapan kedua lebih banyak mendekati orang dewasa. ${ }^{1}$ Ramadhon Muhammad Al-Qazafi ${ }^{2}$ mengelompokkan masa ini pada masa hilm (mimpi) dan masa pemuda.

${ }^{1}$ Lihat Dimyati, Mahmud M., Psikologi Suatu Pengantar, (Yogyakarta: BPFE, 1990), hlm. 150-153.

2 Ramadhon Muhammad Al-Qazafi, Ilm al-Nafs al-Islamiy, (Turablis: Shohifah al-Da wah al-Islamiyah, 1990), hlm. 337.
Salmaini Yeli, Deliquensi Pada Remaja dan Penangoulangannya

Pada masa remaja awal terlihat terjadinya perubahan-perubahan bentuk fisik seperti tumbuhnya payudara dan keluarnya darah haid (menstruasi) pada remaja puteri, berubahnya suara pada pria dan tumbuhnya rambut di sekitar bibir. Dari segi hormon reproduksi mereka sudah dapat berfungsi sebagaimana orang dewasa pada umumnya. Dalam arti kata dapat terjadi pembuahan dan melahirkan generasi baru. Perubahan-perubahan ini menimbulkan perasaan yang beragam pada diri remaja. Ada yang menanggapinya dengan perasaan malu, ada yang takut, ada pula yang bangga karena mereka telah sempurna sebagai seorang pria atau wanita. Sikap yang ditunjukkan anak remaja ini biasanya dipengaruhi oleh apa yang mereka dapatkan dalam keluarga. Seorang remaja puteri yang mengalami menstruasi pertama pada usia 11 tahun dan memiliki saudara perempuan yang mengalami menstruasi pada usia 15 tahun merasa malu dan berusaha menyembunyikan kedatangan haid (menstruasi) yang dialaminya terutama jika dalam keluarga tersebut tidak ada klarifikasi bahwa menstruasi merupakan hal yang memang dan harus dialami oleh seorang wanita, dan dialami secara beragam, ada yang mulai usia 9 tahun. Apalagi jika dalam keluarga tersebut si remaja mendapat ajaran bahwa cepat lambatnya seseorang mengalami menstruasi tergantung pada genit tidaknya seseorang. Namun jika dalam sebuah keluarga si anak mendapat penjelasan bahwa datangnya menstruasi merupakan pertanda bahwa seorang wanita itu normal, maka remaja puteri tersebut akan menyambut kedatangan menstruasi dengan lapang dada dan perasaan bangga. Begitu pula halnya dengan remaja putera yang mengalami perubahan suara dan mimpi basah yang dialaminya. Jika remaja tersebut telah mendapat penjelasan yang cukup memadai tentang perubahan-perubahan yang akan mereka alami tersebut maka mereka akan lebih siap pula menghadapi perubahan-perubahan tersebut. Pada remaja-remaja seperti ini biasanya kurang ditemukan gejala-gejala delinquen. Akan tetapi remaja-remaja yang memiliki keluarga yang kurang harmonis yang kurang berkomunikasi antar anggota keluarga akan sulit menghadapi perubahan-perubahan yang mereka alami pada tahap pertumbuhan dan perkembangan remaja ini, 
Al-Fikra: Jurnal Ilmiah Keislaman, Vol. 7, No. 1, Januari-Juni 2008 sehingga kemungkinan terjadinya gejala delinquensi lebih banyak ditemui.

Pada saat ini anak mulai merasa tertarik pada lawan jenisnya. Dan hal ini tentunya harus pula mendapat perhatian khusus dari orangtua. Pada saat ini anak remaja perlu mendapat penjelasan tentang akibat-akibat yang dapat timbul apabila mereka terlalu dekat dengan lawan jenisnya. Dalam arti kata mereka harus mendapat pendidikan seks yang cukup sehingga tidak bermain-main dengan seks. ${ }^{3}$

Crow \& Crow ${ }^{4}$ melihat mulai berlangsungnya kesadaran seks ini sebagai ciri utama pertumbuhan anak-anak muda baik laki-laki maupun perempuan. Anak perempuan yang berumur 11 atau 12 tahun mungkin akan digelar atau dicap sebagai seorang yang tomboy atau kelaki-lakian, sebaliknya anak laki-laki yang senang bermain dengan anak perempuan di usia seperti ini akan dicap bencong atau keperempuan-perempuanan.

Dari segi pribadi dan perkembangan pola pikir terlihat bahwa remaja awal masih memiliki perkembangan yang masih rendah meskipun pada tahap ini pemikiran mereka berkembang pesat dan masih mengutamakan emosi. Pada tahap perkembangan sosial anak berkembang pesat. Mereka akan dengan senang hati ikut serta dalam kepanitiaan suatu acara, berkumpul-kumpul dengan teman sebaya dan lingkungannya, atau masuk dalam organisasi tertentu. Pada tahap ini anak mulai dapat berpikir abstrak Dari segi materi anak sepenuhnya masih tergantung pada orang tua.

Sesuai dengan hal ini Hurlock mengidentifikasikan beberapa ciri yang terdapat pada tahap perkembangan remaja, yaitu :

1. Masa remaja sebagai periode yang penting

2. Masa remaja sebagai periode peralihan

3. Masa remaja sebagai periode perubahan

4. Masa remaja sebagai usia bermasalah

5. Masa remaja sebagai masa mencari identitas

3 Isdwiputranti BM Titisari, "Bila Remaja Mulai Pacaran", Familia : IV:1, (Yogyakarta: Yayasan Kanisius, 2000), hlm. 50-53.

${ }^{4}$ Lester D. Crow \& Alice Crow, Psikologi Pendidikan Buku 1, diterjemahkan oleh Z. Kasijan, (Surabaya: Bina Ilmu, 1984), hlm. 176.
Salmaini Yeli, Deliquensi Pada Remaja dan Penanggulangannya

6. Masa remaja sebagai usia yang menimbulkan ketakutan

7. Masa remaja sebagai masa yang tidak realistik

8. Masa remaja sebagai ambang masa dewasa ${ }^{5}$

\section{Delinquensi dan Problem Remaja}

Delinquensi berasal dari bahasa Latin "delinquere" yang berarti terabaikan, mengabaikan, yang kemudian diperluas artinya menjadi jahat, asosial, kriminal, pelanggar aturan, pembuat ribut, pengacau, penteror, tidak dapat diperbaiki lagi, durjana, dursila dan lain-lain. Delinquensi itu selalu mempunyai konotasi serangan, kejahatan dan keganasan yang dilakukan oleh anak-anak muda di bawah usia 22 tahun. ${ }^{6}$

Dengan demikian delinquensi pada umumnya dilakukan oleh anak-anak pada usia remaja. Anak-anak remaja yang melakukan kejahatan yang tergolong pada patologi sosial ini pada umumnya terjadi karena kurang memiliki kontrol diri. Kejahatan yang mereka lakukan pada umumnya mempunyai motif subyektif tertentu yaitu untuk mencapai suatu tujuan tertentu yang kadangkala sangat sederhana, atau sebagai pengalihan problem lain yang juga sedang mereka alami.

Munculnya keinginan untuk berkumpul dan bersosialisasi dengan teman sebaya pada remaja yang kemudian memunculkan ganggang di antara mereka menimbulkan berbagai dampak negatif, seperti fanatisme gang, yang dapat menimbulkan perkelahian antar gang jika ada salah satu anggota gangnya yang diganggu atau merasa terganggu oleh anggota gang lainnya. Fenomena ini juga dapat memunculkan bentuk-bentuk perilaku negatif lainnya yang disepakati untuk dilakukan oleh kelompok. Yang penting suara kelompok dan normanorma kelompok yang mereka buat dan atur sendiri harus dipatuhi

5 Elizabeth B. Hurlock, Psikologi Perkembangan Suatu Pendekatan Sepanjang Rentang Kebidupan, diterjemahkan oleh Istiwidayanti dan Soedjarwo, (Jakarta: Erlangga, 1990), hlm : 207-208.

${ }^{6}$ Kartini Kartono, Patologi Sosial 2 Kenakalan Remaja, (Jakarta: Rajawali Pers, 1992), hlm. 9 
A1-Fikra: Jurnal Ilmiah Keislaman, Vol. 7, No. 1, Januari-Juni 2008

oleh anggota-anggota kelompoknya. Jika tidak orang tersebut tidak dapat diterima di dalam gangnya.

Kartini Kartono mengklarifikasi enam motif yang mendorong remaja untuk melakukan delinquensi, yaitu :

1. Untuk memuaskan kecenderungan keserakahan.

2. Meningkatnya agresivitas dan dorongan seksual.

3. Salah-asuh dan salah didik orangtua, sehingga anak menjadi manja dan lemah mentalnya.

4. Hasrat untuk berkumpul dengan kawan senasib dan sebaya, dan kesukaan untuk meniru-niru.

5. Kecenderungan pembawaan yang patologis atau abnormal.

6. Konflik batin sendiri, dan kemudian menggunakan mekanisme pelarian diri serta pembelaan diri yang irrasional. ${ }^{7}$

Pada usia remaja pada dasarnya anak mulai mencari jati dirinya. Mereka mulai merasa bahwa diri mereka telah besar, dan oleh karena itu tidak perlu diatur lagi sebagaimana anak kecil. Mereka ingin keluar dari aturan-aturan yang selama ini dianggap mengekang dan menghambat perkembangan mereka. Semua gejolak yang berupa kejengkelan terhadap aturan dan kungkungan orangtua serasa ingin dikeluarkan. Akan tetapi keterbatasan mereka membuat mereka tak dapat menumpahkan gejolak tersebut dengan leluasa, sehingga muncul konflik dalam diri remaja antara bebas sebebas-bebasnya dari keterikatan dan kungkunagan orang dewasa yang berarti kehilangan semua fasilitas yang selama ini dapat dinikmati dan tetap menjadi anak yang manis.

Selain itu faktor lingkungan tempat anak tinggal, bermain dan sekolah sangat besar andilnya dalam membentuk pribadi anak remaja. Lingkungan, baik lingkungan fisik maupun lingkungan sosial samasama memiliki andil yang kuat dalam membentuk pribadi seseorang. ${ }^{8}$

Adapun kejahatan yang dilakukan para remaja tersebut beragam bentuk dan jenisnya, mulai dari hal-hal kecil yang bersifat sepele

\section{Ibid.}

${ }^{8}$ Bimo Walgito, Pengantar Psikologi Umum, (Yogyakarta: Andi Offset, 1997), hlm. 49 .
Salmaini Yeli, Deliquensi Pada Remaja dan Penanggulangannya

sampai kepada hal-hal yang membahayakan, baik bagi diri mereka maupun orang lain. Di antara perilaku delinquen tersebut adalah :

1. Kebut-kebutan di jalan hingga mengganggu keamanan lalu lintas, dan membahayakan jiwa mereka sendiri serta orang lain.

2. Perilaku ugal-ugalan, berandalan, urakan yang mengacaukan ketenteraman lingkungan. Tingkahlaku ini bersumber pada kelebihan energi dan dorongan primitif yang tidak terkendali serta kesenangan menteror lingkungan.

3. Perkelahian antar gang, antar kelompok, antar sekolah, antar suku (tawuran), yang kadang-kadang sampai menimbulkan korban jiwa.

4. Membolos dari sekolah lalu bergelandang sepanjang jalan, atau bersembunyi di tempat-tempat terpencil sambil melakukan percobaan berbagai macam perilaku delinquen dan tindak a-susila.

5. Kriminalitas anak, remaja dan adolesens antara lain berupa perbuatan mengancam, intimidasi, memeras, maling, mencuri, mencopet, merampas, menjambret, menyerang, merampok, menggarong, melakukan pembunuhan dengan jalan menyembelih korbannya, mencekik, meracun, tindak kekerasan, dan pelanggaran lainnya.

6. Berpesta pora sambil mabuk-mabukan, melakukan hubungan seks bebas, atau orgi (mabuk-mabukkan dan menimbulkan keadaan yang kacau yang mengganggu lingkungan.

7. Perkosaan, agresivitas seksual dan pembunuhan dengan motif seksual, atau didorong oleh reaksi-reaksi kompensatoris dari perasaan inferior, menuntut pengakuan diri, depresi hebat, rasa kesunyian, balas dendam, kekecewaan ditolak cintanya oleh seorang wanita, dan lainlain.

8. Kecanduan dan ketagihan bahan narkotika yang erat bergandengan dengan tindak kejahatan. 
Al-Fikra: Jurnal Ilmiah Keislaman, Vol. 7, No. 1, Januari-Juni 2008

9. Tindak-tindak immoral seksual secara terang-terangan tanpa basa basi, tanpa rasa malu dengan cara yang kasar.

10. Homoseksualitas, erotisme anal dan oral, dan gangguan seksual lain pada anak remaja disertai tindak-tindak sadistis.

11. Perjudian dan bentuk-bentuk permainan lain dengan taruhan, sehingga mengakibatkan ekses kriminalitas.

12. Komersialisasi seks, pengguguran janin oleh gadis-gadis delinquen, dan pembunuhan bayi oleh ibu-ibu yang tidak kawin.

13. Tindakan radikal dan ekstrim, dengan cara kekerasan, penculikan dan pembunuhan yang dilakukan oleh anak-anak remaja.

14. Perbuatan a-sosial dan anti-sosial lain disebabkan oleh gangguan kejiwaan pada anak-anak dan remaja psikopatik, neurotik dan menderita gangguan-gangguan jiwa lainnya.

15. Tindak kejahatan disebabkan oleh penyakit tidur dan ledakan meningitis serta post-encephalitics; juga luka di kepala dengan kerusakan pada otak adakalanya membuahkan kerusakan mental, sehingga orang yang bersangkutan tidak mampu melakukan kontrol-diri.

16. Penyimpangan tingkah-laku disebabkan oleh kerusakan pada karakter anak yang menuntut kompensasi, disebabkan adanya organ-organ yang inferior.

Selain prilaku-prilaku di atas ada juga remaja yang melakukan kebut-kebutan dan balapan motor di jalan yang sepi dan tinju tidak resmi yang tidak memiliki jaminan keselamatan jiwa. Perilaku tersebut kadang-kadang sampai mengakibatkan korban jiwa. Namun demikian perlu pula disadari bahwa banyak pula di antara remaja yang melakukan hal-hal yang positif bahkan berprestasi di bidangnya.

Adapun penyebab terjadinya delinquensi yang tergolong pada patologi sosial dapat dikelompokkan pada empat kelompok, yaitu teori biologis, teori psikogenis, teori sosiogenis dan teori subkultur. Teori biologis berpendapat bahwa delinquensi pada remaja dan anak terjadi karena faktor-faktor fisiologis dan struktur jasmaniah seseorang yang diwarisi melalui gen yang ditelorkan orang tua (hereditas).
Salmaini Yeli, Deliquensi Pada Remaja dan Penanggulangannya

Dengan demikian seorang remaja yang melakukan perbuatan yang tergolong pada delinquensi adalah remaja-remaja yang memang mempunyai bakat untuk melakukan perbuatan delinquen tersebut. Teori psikogenis menekankan terjadinya delinquensi karena aspek psikplogis atau isi kejiwaannya antara lain faktor intelegensi, ciri kepribadian, motivasi, sikap-sikap yang salah, fantasi, rasionalisasi, internalisasi diri yang keliru, konflik batin, emosi yang kontroversal, kecenderungan psikopatologis, dan lain-lain. Menurut teori ini anakanak atau remaja yang melakukan perbuatan yang tergolong pada perbuatan delinquensi adalah anak atau remaja yang memiliki konflik dan masalah yang berhubungan dengan dirinya sendiri, umpamanya sebagai pelarian terhadap kekuarangan-kekurangan yang mereka miliki, kurang mendapatkan kasih sayang dan sebagainya. Teori sosiogenis berpendapat bahwa penyebab terjadinya delinquensi adalah murni faktor sosiologis atau sosial-psikologis sifatnya, misalnya karena pengaruh struktur sosial yang menyimpang, tekanan kelompok, peranan sosial, status sosial atau oleh internalisasi simbolis yang keliru. Teori subkultur mengaitkan terjadinya delinquensi dengan sistem nilai, kepercayaan/keyakinan, ambisi-ambisi tertentu yang memotivasi timbulnya kelompok-kelompok remaja brandalan dan kriminal Sedang perangsangnya bisa berupa hadiah mendapatkan status sosial terhormat di tengah kelompoknya, prestise sosial, relasi sosial yang intim dan hadiah-hadiah materil lainnya. Menurut teori ini sumber terjadinya delinqunsi adalah sifat-sifat suatu struktur sosial dengan pola budaya (subkultur) yang khas dari lingkungan familial, tetangga dan masyarakat yang didiami oleh para remaja delinquen tersebut. ${ }^{9}$

Agaknya perlu pula disadari bahwa masa remaja ini merupakan masalah yang penuh masalah dan kebimbangan. Banyak masalah yang dihadapi remaja, yang secara umum dapat dikelompokkan pada masalah dengan orang tua, di mana karena remaja yang mulai mengalami perkembangan berpikir sering membantah perintah dan ucapan orangtua terutama jika apa yang disampaikan orangtua tersebut mereka anggap tidak masuk akal. Masalah lain yang juga dihadapi remaja adalah masalah hari depan, karena mereka mulai

${ }^{9} \mathrm{Ibid}, \mathrm{hlm} .25-32$ 
Al-Fikra: Jurnal Ilmiah Keislaman, Vol. 7, No. 1, Januari-Juni 2008

menyadari bahwa mereka telah sama dari segi fisik dengan orang dewasa, hanya saja mereka masih harus bergantung pada orang tua karena belum mampu memenuhi kebutuhannya sendiri. Remaja juga mempunyai masalah moral dan agama, di mana ketika masih kanakkanak mereka bebas berteman dengan siapa saja baik dengan teman sejenis maupun dengan lawan jenisnya, namun ketika menanjak usia remaja semua yang mereka lakukan seakan menjadi sorotan, mereka tidak lagi boleh seenaknya berteman dengan lawan jenisnya, tidak lagi boleh berpakaian seenaknya dan lain sebagainya. Dari segi agama mereka sudah memiliki beban-beban tertentu yang harus mereka lakukan sebagaimana halnya yang dilakukan orang dewasa.

\section{Perkembangan Agama pada Remaja}

W. Starbuck sebagaimana yang dikutip Jalaluddin ${ }^{10}$ menyatakan bahwa perkembangan agama pada remaja diatandai oleh fakor perkembangan rohani dan jasmaninya, seperti pertumbuhan pikiran dan mental, perkembangan perasaan, pertimbangan sosial, perkembangan moral.

Hasil penelitian Allport, Gillesphy dan Young menunjukkan bahwa 85\% remaja Katolik Romawi taat menganut agamanya, dan hanya 40\% remaja Protestan yang tetap taat menjalankan agamanya. Penelitian ini menunjukkan bahwa agama yang ajarannya lebih konservatif-dogmatis lebih banyak berpengaruh bagi para remaja untuk tetap taat pada ajaran agamanya, sementara ajaran agama yang lebih moderat dan agak liberal yang mudah merangsang perkembangan pikiran dan mental remaja dapat merangsang pikiran dan mental remaja tersebut untuk meninggalkan ajaran agama itu sendiri.

Oleh karena perkembangan pikiran dan mentalnya, pada diri remaja sering terjadi konflik dan keraguan terhadap agama. Penelitian W. Starbuck terhadap 142 orang mahasiswa Middleburg College, memperlihatkan bahwa 53\% dari sampel tersebut mengalami konflik

10 Jalaluddin, Psikologi Agama Memahami Perilaku Keagamaan dengan mengaplikasikan prinsip-prinsip psikologi. (Jakarta: t.p., 2005), hlm. 74-77.
Salmaini Yeli, Deliquensi Pada Remaja dan Penanggulangannya

dan keraguan terhadap ajaran agama. Bahkan ketika penelitian serupa dilakukan terhadap 95 orang mahasiswa ternyata $75 \%$ di antaranya mengalami konflik dan keraguan terhadap ajaran agama. ${ }^{11}$

Starbuck mengemukakan beberapa penyebab timbulnya keraguaan pada remaja yaitu :

1. Faktor kepribadian yang menyangkut salah tafsir dan jenis kelamin

2. Kesalahan organisasi keagamaan dan pemuka agama

3. Pernyataan kebutuhan manusia

4. Kebiasaan

5. Pendidikan

6. Percampuran agama dan mistik. ${ }^{12}$

Kepribadian merupakan karakteristik seseorang, sifat khas seseorang yang menyebabkan seseorang mempunyai sifat yang berbeda dari orang lain. Orang yang memiliki kepribadian ekstrovert sanguinis yang selalu terbuka dan ceria biasanya lebih dapat mengkomunikasikan semua gejolak yang dirasakannya kepada orang lain. Remaja dengan karakteristik seperti ini akan lebih kecil peluangnya dalam mengalami konflik, sementara remaja dengan kepribadian melankolis dan introvert yang tidak mampu mengkomunikasikan semua problem yang dihadapi kepada orang lain akan lebih mudah mengalami keraguan, terutama jika mendapatkan pertentangan-pertentangan antara ajaran agama dengan realitas yang dihadapi. Demikian pula halnya dengan perbedaan jenis kelamin akan mempengaruhi perilaku remaja. Remaja putri yang lebih cepat mengalami kematangan, disinyalir akan lebih cepat pula mengalami keraguan dalam ajaran agama dibanding anak laki-laki.

Organisasi keagamaan yang cenderung mengedepankan perbedaan antar organisasi dalam hal paham keagamaan dapat memicu terjadinya keraguan dalam diri remaja terhadap realitas agama yang sesungguhnya.

Keraguan dan konflik dapat pula disinyalir sebagai kodrat dan bawaan yang memang sudah dibawa dan dimiliki oleh setiap manusia

1 Ibid, hlm. 78-79.

12 Lihat Ibid, hlm. 78-80. 
A1-Fikra: Jurnal Ilmiah Keislaman, Vol. 7, No. 1, Januari-Juni 2008

semenjak ia lahir. Manusia terdorong untuk mendalami ajaran agama sebagai kebutuhan hidupnya, dan jika terjadi perbedaan antara ajaran agama dengan harapannya akan muncul konflik dalam dirinya.

Ajaran yang diterima remaja dari keluarganya pada umumnya dilakukan sebagai kebiasaan dan rutinitas, sehingga ketika kebiasaan tersebut bertemu dengan ajaran lain yang bebeda dengan ajaran yang biasa dianut, memungkinkan terjadinya keraguan kepada agama baru tersebut.

Pendidikan yang biasanya memberi peluang remaja untuk berpikir kritis dapat pula mempengaruhi terjadinya konflik dan keraguan dalam diri remaja. Pada remaja yang berpendidikan akan lebih kritis terhadap ajaran agama yang banyak mengandung ajaranajaran dogmatis, dan dapat menimbulkan keraguan dalam diri remaja tersebut terhadap ajaran agama yang menurutnya bertentangan dengan pikiran tersebut. Remaja sering pula mengalami keraguan terhadap ajaran-ajaran agama yang seringkali dicampuradukkan dengan ajaran mistis.

Selain faktor-faktor di atas menurut hemat penulis kebiasaan di rumah tangga juga menjadi pemicu terjadinya konflik terhadap ajaran agama pada remaja. Pada keluarga yang membiasakan kehidupan beragama yang taat dan selalu menjalankan ajaran agama dengan baik akan mengurangi konflik yang terjadi pada diri remaja. Sebaliknya pada keluarga yang liberal dan kurang menjalankan ajaran agama dengan baik, maka akan membuka peluang terjadinya konflik keagamaan pada diri remaja. Pada keluarga remaja di mana orangtuanya merupakan seorang otoriter yang tidak membiasakan diskusi dalam masalah agama dengan anak dan remaja akan lebih memicu terjadinya konflik pada diri remaja manakala seiring perkembangan mental dan pikirannya mereka mulai menalar ajaran agama dengan cara mereka sendiri. Ketika terjadi benturan-benturan mengenai ajaran agama mereka tidak berani mendiskusikannya kepada orangtua, sehingga keraguan tersebut akan terus berlanjut. Sebaliknya pada keluarga yang demokratis yang selalu mendiskusikan apa saja permasalahan yang dialami anggota keluarga akan lebih mudah
Salmaini Yeli, Deliquensi Pada Remaja dan Penanggulangannya mengatasi konflik dan keraguannya terhadap ajaran agama dengan mendialogkannya bersama orangtua.

\section{Usaha-Usaha Peralihan terhadap Delinquensi}

Tindakan-tindakan yang dilakukan remaja perlu mendapat perhatian khusus dari orang dewasa, baik dengan mencegah sebelum perbuatan tersebut terjadi maupun menanggulangi jika perbuatan tersebut telah terlanjur terjadi. Kartini Kartono ${ }^{13}$ mengelompokkan dua garis besar upaya yang dapat dilakukan untuk mengatasi problem delinquensi, yaitu dengan cara preventif dan cara kuratif. Tindakan preventif yang dapat dilakukan berupa :

1. Meningkatkan kesejahteraan keluarga.

2. Perbaikan lingkungan,

Kartini Kartono ${ }^{14}$ mengemukakan 14 hal yang dapat dilakukan untuk mencegah terjadinya delinquensi, yaitu :

1. Meningkatkan kesejahteraan keluarga.

2. Perbaikan lingkungan, yaitu daerah slum, kampungkampung miskin.

3. Mendirikan klinik bimbingan psikologis dan edukatif untuk memperbaiki tingkah laku dan membantu remaja dari kesulitan mereka.

4. Menyediakan tempat rekreasi yang sehat bagi remaja.

5. Membentuk badan kesejahteraan anak-anak.

6. Mengadakan panti asuhan.

7. Mengadakan lembaga reformatif untuk memberikan latihan korektif, pengoreksian dan asistensi untuk hidup mandiri dan susila kepada anak-anak dan para remaja yang membutuhkan.

8. Membuat badan supervisi dan pengontrol terhadap kegiatan anak delinquen, disertai program yang korektif.

9. Mengadakan pengadilan anak.

${ }^{13}$ Kartini, Patologi Sosial ... hlm. 96-97.

${ }^{14}$ Ibid. 
Al-Fikra: Jurnal Ilmiah Keislaman, Vol. 7, No. 1, Januari-Juni 2008

10. Menyusun undang-undang khusus untuk pelanggaran dan kejahatan yang dilakukan oleh anak dan remaja.

11. Mendirikan sekolah bagi anak gembel (miskin).

12. Mengadakan rumah tahanan khusus untuk anak dan remaja.

13. Menyelenggarakan diskusi kelompok dan bimbingan kelompok untuk membangun kontak manusiawi di antara para remaja delinquen dengan masyarakat luar. Diskusi tersebut akan sangat bermanfaat bagi pemahaman kita mengenai jenis kesulitan dan gangguan pada para remaja.

14. Mendirikan tempat latihan untuk menyalurkan kreatifitas para remaja delinquen dan yang nondelinkuen.

Tindakan kuratif yang dapat dilakukan sebagai upaya pengalihan perilaku delinquen antara lain berupa :

1. Menghilangkan semua sebab-musabab timbulnya kejahatan remaja, baik yang berupa pribadi, familial, sosial-ekonomis dan kultural.

2. Melakukan perubahan lingkungan dengan jalan mencarikan orang tua angkat/asuh dan memberikan fasilitas yang diperlukan bagi perkembangan jasmani dan rohani yang sehat bagi anak-anak remaja.

3. Memindahkan anak-anak nakal ke sekolah yang lebih baik, atau ke tengah lingkungan sosial yang baik.

4. Memberikan latihan bagi para remaja untuk hidup teratur, tertib dan berdisiplin.

5. Memanfaatkan waktu senggang di kamp latihan, untuk membiasakan diri bekerja, belajar dan melakukan rekreasi sehat dengan disiplin tinggi.

6. Menggiatkan organisasi pemuda dengan program-program latihan vokasional untuk mempersiapkan anak remaja delinquen itu bagi pasaran kerja dan hidup di tengah masyarakat.

7. Memperbanyak lembaga latihan kerja dengan program kegiatan pembangunan.

8. Mendirikan klinik psikologi untuk meringankan dan memecahkan konflik emosional dan gangguan kejiwaan
Salmaini Yeli, Deliquensi Pada Remaja dan Penanggulangannya

lainnya. Memberikan pengobatan medis dan terapi psikoanalitis bagi mereka yang menderita gangguan kejiwaan.

Dari uraian mengenai remaja di atas dapat dipahami bahwa masa remaja merupakan masa-masa sulit yang dialami seseorang dan merupakan masa yang penuh persoalan, baik persoalan pisik, maupun persoalan psikis. Oleh karena itu pada masa ini anak memerlukan kesiapan agar dapat melalui masa ini dengan problem yang agak kurang. Untuk itu diperlukan peranan orang dewasa di dalamnya untuk memberi pemahaman tentang kondisi-kondisi yang mungkin mereka alami di masa remaja. Sudah selayaknya jika orang tua memberi tahu anak bahwa suatu saat mereka akan menanjak remaja kemudian dewasa. Dan pada saat itu mereka akan mengalami hal-hal yang menyenangkan dan yang tidak menyenangkan. Bahwa mereka akan mengalami perubahan pisik dan juga psikis. Bahwa apa yang mereka alami tersebut adalah normal dan dialami oleh semua orang yang memiliki jenis kelamin yang sama dengan mereka. Pada masa ini anak memerlukan seseorang untuk tempat ia mencurahkan hatinya. Jika pada masa ini ia tidak memiliki orang tua atau orang dewasa lainnya tempat ia mencurahkan isi hati dan permasalahan pribadinya, maka ia akan mencari hal itu di luar rumah, dan jika apa yang ia dapatkan tersebut mengarahkan ia untuk melakukan hal-hal yang positif maka terhindarlah ia dari melakukan hal-hal yang negatif. Sebaliknya jika subyek tersebut mengarahkan ia untuk berbuat negatif maka terjadilah perbuatan delinquensi yang sering meresahkan masyarakat.

\section{Kesimpulan}

Pada dasarnya banyak hal-hal positif yang ada pada diri remaja jika perkembangan yang terjadi pada diri mereka diarahkan ke arah yang positif dan dikembangkan semaksimal mungkin. Perkembangan sosial remaja yang mengarah kepada pembentukan gang-gang umpamanya dapat diarahkan pada organisasi-organisasi yang dapat membentuk watak remaja tersebut yang sebaiknya diarahkan orang dewasa, karang taruna misalnya sehingga remaja tersebut tidak 
A1-Fikra: Jurnal Ilmiah Keislaman, Vol. 7, No. 1, Januari-Juni 2008

terfokus pada kelompok gang-gang yang banyak hal negatifnya. Remaja dapat pula diberi tugas-tugas sosial kemanusiaan untuk mengisi waktu-waktu senggang mereka, hingga mereka kurang atau bahkan tidak memiliki waktu untuk memikirkan hal-hal yang negatif. Dari pengalaman ternyata banyak remaja yang melakukan hal-hal positif di usia yang tergolong masih dini, adanya grup-grup band anak muda umpamanya menandakan bahwa banyak juga remaja yang berbuat hal-hal positif di usia remajanya. Kecenderungan remaja untuk menjadi jagoan yang dinyatakan dalam bentuk perkelahian dapat diarahkan pada klub-klub tinju yang melatih kemampuan mereka dalam bertarung. Kecenderungan remaja untuk kebut-kebutan dapat diarahkan ke klub balapan yang profesional, sehingga apa yang mereka lakukan tidak merugikan diri mereka sendiri dan tidak pula meresahkan masyarakat lingkungan tempat mereka berada.

\section{Bibliografi}

Crow, Lester D. \& Alice Crow, Psikologi Pendidikan Buku 1, (terjemahan : Z. Kasijan), (Surabaya: Bina Ilmu, 1984).

Dimyati, Mahmud M., Psikologi Suatu Pengantar, (Yogyakarta: BPFE, 1990.

Hurlock, Elizabeth B., Psikologi Perkembangan Suatu Pendekatan Sepanjang Rentang Kehidupan, (penterjemah : Istiwidayanti dan Soedjarwo), (Jakarta: Erlangga, 1990).

Isdwiputranti BM Titisari, "Bila Remaja Mulai Pacaran", Familia: IV:1, (Yogyakarta: Yayasan Kanisius, 2000).

Jalaluddin, Psikologi Agama Memahami Perilaku Keagamaan dengan Mengaplikasikan PrinsipPprinsip Psikologi. (Jakarta: t.p., 2005).

Kartono, Kartini, Patologi Sosial dan Kenakalan Remaja, (Jakarta: Rajawali Pers, 1992).

Walgito, Bimo, Pengantar Psikologi Umum, Yogyakarta: Andi Offset, 1997). 